\title{
Accounting
}

\section{Determinants of consumer financial behavior: Evidence from households in Indonesia}

\author{
Sri Zulaihatia and Umi Widyastuti ${ }^{*}$
}

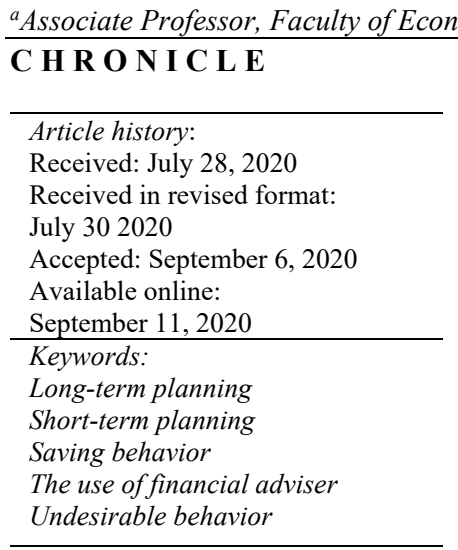

(C) 2021 by the authors; licensee Growing Science, Canada

\section{Introduction}

Refers to the 2019's National survey conducted by the Financial Service Authority (Otoritas Jasa Keuangan), the level of Indonesian's financial literacy index was 38,03 percent (OJK, 2020). The survey also showed that Indonesian's financial inclusion index was 73.88 percent. According to Widyastuti, Sumiati, Susanti, and Suherman (2019), there were some barriers to financial inclusion, including low income and lack of sufficient citizen's legal document. By surveying the household across the countries in the world, Atkinson, Monticone, and Mess (2016) described that the low level of financial literacy leads to poor financial behavior. They found that budgeting did not become a priority, even though it has proven that planning for the future was beneficial by money management. Several studies have been conducted to describe the household's financial behavior, while financial behavior is commonly explored in many specific types of behavior. East (1993), Bateman, Louviere, Thorp, Islam, and Satchell (2017) and Hassan Al-Tamimi and Anood Bin Kalli (2009) attempted to discuss investment decision making, while some others explore saving behavior (Brounen, Koedijk, \& Pownall, 2016; Chatterjee, Fan, Jacobs, \& Haas, 2017). Thus, this study is conducted to develop the construct of financial behavior by determining the dimensions of financial behavior.

\section{Literature Review}

Financial behavior is defined as any human behavior related to money management (Xiao, 2008). As reported by Henager and Cude (2016) and Zulaihati, Susanti, and Widyastuti (2020), financial behavior can be categorized into two types of behavior based on period, namely short-term and long-term financial behavior. They supported the concept of financial behavior which

* Corresponding author

E-mail address: umiwidyastuti_feunj@unj.ac.id (U. Widyastuti) 
is developed by Huston (2010) who focused on short-term planning and long-term planning. Several studies have attempted to conceptualized financial behavior using several dimensions. Atkinson et al. (2016) measured financial behavior that reflected some dimensions namely: budgeting, thinking before making a purchase, paying bills on time, saving, and borrowing to make ends meet. In line with them, de Bassa Scheresberg (2013) had three subsets of financial behavior associated with day-to-day and long-term financial management reflecting in high-cost methods of borrowing, holding a buffer stock of savings, and planning for retirement. While Dewi, Febrian, Effendi, and Anwar (2020) explored financial behavior by measuring three kinds of behavior, including pay bills on time, investment diversification, and retirement investment. Therefore, financial behavior could be defined in many terms of financial decisions related to money management. Nowadays, financial behavior has been exploring as an interesting topic of research. Huston (2010) stated that financial behavior played an important role in achieving someone's financial well-being. This is also supported by de Bassa Scheresberg (2013), who found that financial behavior can be critical to young adults' financial wellbeing.

\section{Research Methodology}

Williams et al. (2010) stated that exploratory factor analysis (EFA) can be applied for many purposes. It can be used to reduce a large number of variables into a smaller set of variables (also known as factors or components or dimensions), and also establishes underlying dimensions between measured variables and latent constructs, thereby allowing the formation and refinement of theory. Therefore, this study aims to determine the dimensions of financial behavior. Using a questionnaire which consists of 21 indicators, the primary data were collected conveniently from 229 households in Indonesia. The procedures in EFA is started by the test of the adequacy of sample size. Refer to Hair Jr., Black, Babin, and Anderson (2019), this test applied two criteria in assessing the sufficiency of the data in factor analysis, namely: Kaiser Meyer Olkin - Measure of Sampling Adequacy (KMO - MSA) and Bartlett's Test of Sphericity. The first criterion is KMO-MSA which should be between 0 to 1 . If the KMO-MSA exceeds 0.5 , it could be said that the data is suitable for factor analysis. The second criterion is Bartlett's Test of Sphericity. Bartlett's test of sphericity should be significant $(\mathrm{p}<0.05)$, therefore this could be concluded that the factor analysis is suitable. If the requirement of sample size has been fulfilled, the next step is the reduction of a large number of variables into the dimensions using the principal component analysis (PCA), as one of the extraction methods. Some approaches can be used to determine the factor extraction, including the Eigenvalue, cumulative percent of variance extracted, and scree plot test (Williams et al., 2010), This study used all of the criteria for the procedure of factor extraction. The factor will be formed when the Eigenvalue is more than 1, while the cumulative percent of variance results from the eigenvalue. LorenzoSeva (2013) explained that if the eigenvalues are added, the result shown total variance in the correlation matrix. The percentage of explained variance of each component can be easily computed as the corresponding eigenvalue divided by the total variance. Hinkin (1998) argues that 60 percent should be a "minimum" value of the percentage of explained variance.

Another criterion in determining factor extraction is the rotation method. This study applied the varimax rotation to represent the factor that uncorrelated. After the rotation step, the final procedure is to give the label for the factor extracted by referring to the theory or relevant research.

\section{Results and Discussion}

The EFA is the analysis which is used to extract a large number of a variable into dimensions. Table 1 displays the value of antiimage correlation for each item that measures financial behavior. Based on the anti-image correlation, we know that all of the items were valid because the value of the anti-image correlation exceeds 0.5 . Therefore the EFA analysis could proceed into the next step.

Table 1

Anti Image Correlation

\begin{tabular}{cccccc}
\hline Items & $\begin{array}{c}\text { Anti-image } \\
\text { correlation }\end{array}$ & Items & $\begin{array}{c}\text { Anti-image } \\
\text { correlation }\end{array}$ & Items & $\begin{array}{c}\text { Anti-image } \\
\text { correlation }\end{array}$ \\
\hline FB1 & 0.863 & FB 7 & 0.516 & FB 13 & 0.671 \\
Inti-image & FB 19 & 0.907 & 0.67 \\
FB2 & 0.904 & FB 8 & 0.57 & FB 14 & FB 20 \\
FB3 & 0.881 & FB 9 & 0.927 & FB 15 & FB 21 \\
FB4 & 0.914 & FB 10 & 0.897 & FB 16 & 0.916 \\
FB5 & 0.831 & FB 11 & 0.907 & FB 17 & 0.884 \\
\hline
\end{tabular}

After the validity test, the next step in EFA is the test of adequacy sample size based on KMO-MSA and Bartlett's test of sphericity. As represented in Table 2, this study has the KMO-MSA 0.877, while Barlett's test of sphericity is significant at 5 percent level of significance. Based on both criteria, it means that this study has a sufficient sample size to be analyzed using EFA. Therefore, the step could proceed further. 
Table 2

Kaiser-Meyer-Olkin Measure of Sampling Adequacy

\begin{tabular}{ccc} 
Kaiser-Meyer-Olkin Measure of Sampling Adequacy. & .877 \\
Bartlett's Test of Sphericity & Approx. Chi-Square & 2587.404 \\
& $\mathrm{df}$ & 210 \\
& Sig. & .000 \\
\hline
\end{tabular}

In this study, the factor extraction is conducted by applying PCA. The findings show in the scree plot in Fig. 1 that represents the number of factors extracted based on the Eigenvalue $>1$.

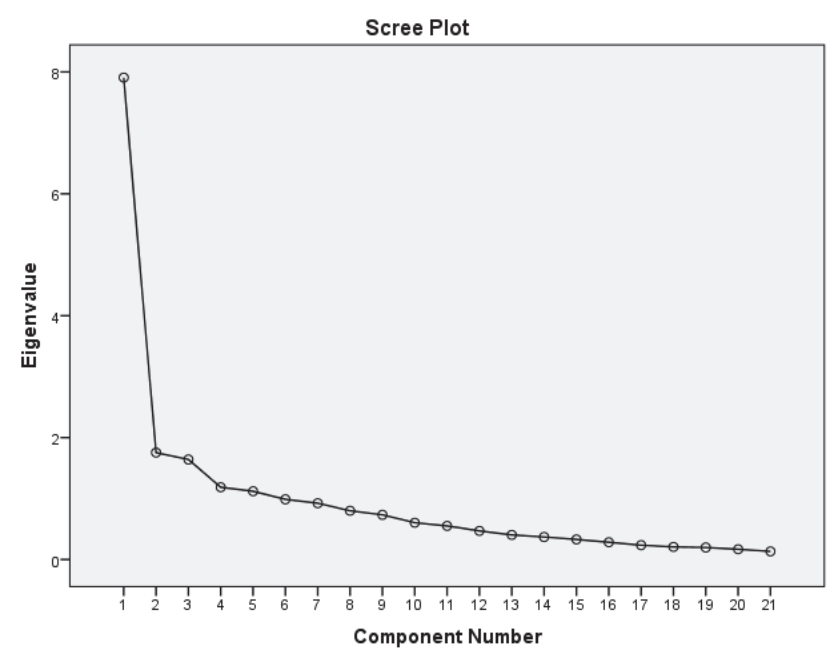

Fig. 1. Scree Plot for Factors Extraction

This figure is reinforced by the result of factor extraction based on the Eigenvalue represented in Table 3. Based on Table 3, five factors have been extracted from this analysis. Each factor has the Eigenvalue as follows: 7.908 for the first factor; 1.755 for the second factor; 1.641 for the third factor; 1.185 for the fourth factor; and 1.120 for the latest factor. Another criterion in factor extraction is the total cumulative variance. According to Hinkin (1998), the minimum value of total cumulative variance which is accepted in EFA is sixty percent. This study has a total variance explained by five factors in the amount of 64.80 percent.

Table 3

Total Variance Explained

\begin{tabular}{|c|c|c|c|c|c|c|}
\hline \multirow[b]{2}{*}{ Component } & \multicolumn{3}{|c|}{ Initial Eigenvalues } & \multicolumn{3}{|c|}{ Extraction Sums of Squared Loadings } \\
\hline & Total & $\%$ of Variance & Cumulative $\%$ & Total & $\%$ of Variance & Cumulative $\%$ \\
\hline 1 & 7.908 & 37.657 & 37.657 & 7.908 & 37.657 & 37.657 \\
\hline 2 & 1.755 & 8.356 & 46.013 & 1.755 & 8.356 & 46.013 \\
\hline 3 & 1.641 & 7.814 & 53.827 & 1.641 & 7.814 & 53.827 \\
\hline 4 & 1.185 & 5.643 & 59.470 & 1.185 & 5.643 & 59.470 \\
\hline 5 & 1.120 & 5.332 & 64.802 & 1.120 & 5.332 & 64.802 \\
\hline 6 & .987 & 4.699 & 69.501 & & & \\
\hline 7 & .923 & 4.397 & 73.898 & & & \\
\hline 8 & .799 & 3.805 & 77.704 & & & \\
\hline 9 & .732 & 3.488 & 81.192 & & & \\
\hline 10 & .604 & 2.875 & 84.067 & & & \\
\hline 11 & .552 & 2.627 & 86.694 & & & \\
\hline 12 & .469 & 2.234 & 88.928 & & & \\
\hline 13 & .404 & 1.924 & 90.852 & & & \\
\hline 14 & .370 & 1.760 & 92.612 & & & \\
\hline 15 & .330 & 1.571 & 94.183 & & & \\
\hline 16 & .283 & 1.345 & 95.529 & & & \\
\hline 17 & .235 & 1.119 & 96.648 & & & \\
\hline 18 & .207 & .984 & 97.632 & & & \\
\hline 19 & .197 & .937 & 98.569 & & & \\
\hline 20 & .168 & .799 & 99.368 & & & \\
\hline 21 & .133 & .632 & 100.000 & & & \\
\hline
\end{tabular}

Note: Extraction Method is Principal Component Analysis. 
The rotation method using varimax is conducted to determine the loading factor for each item and to categorize the items which built each factor. Hinkin (1998) stated that the loading factor is greater than 0.4. The first component or factor consists of five items namely: item number $17,20,16,18$, and 21 . The second component or factor consists sof eight items, including item number $12,10,15,11,14,4,9$, and 3 . The third component or factor consists of four items, including item number 7, 5, 1, and 2. The fourth component or factor consists of two items namely: item number 19 and 13 . The fifth factor consists of two items that reflect the latest dimension. The detail loading factor for each item is represented in Table 4, while the details of the items in each dimension are displayed in Table 5.

\section{Table 4}

Rotated Component Matrix

\begin{tabular}{|c|c|c|c|c|c|}
\hline & \multicolumn{5}{|c|}{ Component } \\
\hline & 1 & 2 & 3 & 4 & 5 \\
\hline VAR00017 & .846 & .244 & & .160 & \\
\hline VAR00020 & .798 & .224 & & .105 & \\
\hline VAR00016 & .795 & .306 & & .156 & \\
\hline VAR00018 & .725 & .244 & .152 & .206 & -.279 \\
\hline VAR00021 & .697 & .332 & .138 & & \\
\hline VAR00012 & .279 & .729 & .134 & .248 & -.218 \\
\hline VAR00010 & .166 & .718 & .206 & .275 & -.232 \\
\hline VAR00015 & .450 & .704 & & & \\
\hline VAR00011 & .445 & .695 & & .173 & \\
\hline VAR00014 & .421 & .684 & & & \\
\hline VAR00004 & .379 & .546 & .176 & & -.144 \\
\hline VAR00009 & & .454 & .183 & .428 & -.277 \\
\hline VAR00003 & .323 & .449 & .340 & -.136 & .180 \\
\hline VAR00007 & & & .710 & & \\
\hline VAR00005 & .189 & .218 & .708 & & -.314 \\
\hline VAR00001 & & .191 & .687 & & \\
\hline VAR00002 & .405 & .446 & .481 & -.137 & \\
\hline VAR00019 & .220 & & & .866 & \\
\hline VAR00013 & .101 & .190 & & .862 & .134 \\
\hline VAR00006 & & -.290 & & & .690 \\
\hline VAR00008 & -.172 & .103 & & & .647 \\
\hline
\end{tabular}

Note: Extraction Method: Principal Component Analysis.

Rotation Method: Varimax with Kaiser Normalization.

a. Rotation converged in 10 iterations.

Table 5

Dimensions of Financial Behavior

\begin{tabular}{|c|c|c|c|}
\hline Dimension & No of Items & Items of Financial Behavior & Loading \\
\hline \multirow[t]{5}{*}{ Long-term planning } & FB17 & Decide beforehand how to use money in the next 1-2 years. & .846 \\
\hline & FB20 & Look at the budget for the next $1-2$ years & .798 \\
\hline & FB16 & Set financial goals for the next 1-2 years. & .795 \\
\hline & FB18 & Consider the steps that need to take to stick to the budget in the next 1-2 years. & .725 \\
\hline & FB21 & Planned out my finance in the next $1-2$ years. & .697 \\
\hline \multirow[t]{8}{*}{ Short-term budgeting } & FB12 & Consider the steps that need to take to stick to the budget in the next 1-2 months. & .729 \\
\hline & FB10 & Set financial goals for the next 1-2 months. & .718 \\
\hline & FB15 & Planned out my finance in the next $1-2$ months. & .704 \\
\hline & FB11 & Decide beforehand how to use money in the next $1-2$ months. & .695 \\
\hline & FB14 & Look at the budget for the next 1-2 months. & .684 \\
\hline & FB4 & Do a good job of budgeting my money. & .546 \\
\hline & FB9 & Checking account. & .454 \\
\hline & FB3 & Saving money, no matter what. & .449 \\
\hline \multirow[t]{4}{*}{ Saving behavior } & FB7 & Buying items on sale. & .710 \\
\hline & FB5 & Comparing prices when shopping & .708 \\
\hline & FB1 & Saving money by packing the lunch instead of buying it out. & .687 \\
\hline & FB2 & Saving money for the future is something I think about. & .481 \\
\hline \multirow{2}{*}{$\begin{array}{l}\text { The use of the financial } \\
\text { adviser }\end{array}$} & FB19 & Consulting the long-term budget. & .866 \\
\hline & FB13 & Consulting the short-term budget. & .862 \\
\hline \multirow[t]{2}{*}{ Undesirable behavior } & FB6 & Impulse buying. & .690 \\
\hline & FB8 & Having difficulties in paying all the expenses and bills. & .647 \\
\hline
\end{tabular}

After the rotation method using varimax, the five factors that have been extracted will be labeled by referring to the previous research. According to Wagner (2015), the first factor is named as long-term planning. This factor reflects the individual's planning behavior related to future spending, budgeting, and setting financial goals in the future, especially in the next 1-2 years. It is also supported by Henager and Cude (2016) who categorize financial behavior into two types of the period including short- 
term and long-term financial behavior. According to Henager and Cude (2016) and Wagner (2015), the second factor is labeled as a short-term planning. This factor represents someone's financial behavior that is related to the short-term financial goals, checking account routinely, planning in spending money, and doing a budget for the next 1-2 months coming. The third factor reflects the behavior to save more money by doing shopping when there is a sale, comparing price before shopping, saving money by packing the lunch instead of buying it and the awareness of saving money for the future. These factors are named as saving behavior by referring to Knoll and Houts (2012) and Varcoe, Martin, Devitto, and Go (2005).

The fourth factor is labeled as the use of financial advisers. It measures people's behavior in consulting their budget to the adviser both for the long-term and short-term periods. This label refers to Wagner (2015) who explore financial behavior in terms of long-term and short-term behavior. The latest factor is labeled as undesirable behavior which reflects in an impulse buying behavior and the difficulties in paying all the bills. It is supported by Xiao, Tang, Serido, and Shim (2011).

Based on the data analysis, the findings show that the dimensions of financial behavior in this study are categorized into five types of financial behavior, including long-term planning, short-term planning, saving behavior, the use of financial adviser, and undesirable behavior.

\section{Conclusion}

This study aimed to identify potential underlying dimensions of financial behavior. Based on factor analysis, five factors of financial behavior are extracted, and these factors are labeled as follows: the first factor is long-term planning, the second factor is short-term planning, the third factor is saving behavior, the fourth factor is the use of financial advisers, and the last one is undesirable behavior. The study used the households without grouping the sample into different incomes. Therefore, it should be applied for the next study to describe each type of behavior and compare the results for each group of income. This implies for future research to explore each dimension related to another variable in explaining the consequences of financial behavior.

\section{Acknowledgement}

The authors would like to express their gratitude to both the anonymous reviewers and the editors for their very helpful input which enabled the authors to make significant improvements to this paper.

\section{References}

Atkinson, A., Monticone, C., \& Mess, F. (2016). OECD/INFE International Survey of Adult Financial Literacy Competencies. Technical Report, OECD.

Bateman, H., Louviere, J., Thorp, S., Islam, T., \& Satchell, S. (2017). Investment decisions for retirement savings. The Journal of Consumer Affairs, 44(3), 463-482.

Brounen, D., Koedijk, K. G., \& Pownall, R. A. (2016). Household financial planning and savings behavior. Journal of International Money and Finance, 69, 95-107.

Chatterjee, S., Fan, L., Jacobs, B., \& Haas, R. (2017). Risk tolerance and goals-based savings behavior of households: The role of financial literacy. Journal of Personal Finance, Forthcoming. Retrieved from https://ssrn.com/abstract=2918014

de Bassa Scheresberg, C. (2013). Financial literacy and financial behavior among young adults: Evidence and implications. Numeracy, 6(2), 5.

Dewi, V. I., Febrian, E., Effendi, N., \& Anwar, M. (2020). Does financial perception mediating the financial literacy on financial behavior? A study of academic community in central Java Island, Indonesia. Montenegrin Journal of Economics, 16(2), 3348.

East, R. (1993). Investment decisions and the Theory of Planned Behaviour. Journal of Economic Psychology, 14(2), 337-375.

Hair Jr., J. F., Black, W. C., Babin, B. J., \& Anderson, R. E. (2019). Multivariate data analysis: Cengage.

Hassan Al-Tamimi, H. A., \& Anood Bin Kalli, A. (2009). Financial literacy and investment decisions of UAE investors. The Journal of Risk Finance, 10(5), 500-516.

Henager, R., \& Cude, B. J. (2016). Financial literacy and long- and short-term financial behavior in different age groups. Journal of Financial Counseling and Planning, 27(1), 3-19. doi:10.1891/1052-3073.27.1.3

Hinkin, T. R. (1998). A brief tutorial on the development of measures for use in survey questionnaires. Organizational Research methods, 1(1), 104-121.

Huston, S. J. (2010). Measuring financial literacy. Journal of Consumer Affairs, 44(2), 296-316.

Knoll, M. A., \& Houts, C. R. (2012). The financial knowledge scale: An application of item response theory to the assessment of financial literacy. Journal of Consumer Affairs, 46(3), 381-410.

Lorenzo-Seva, U. (2013). How to report the percentage of explained common variance in exploratory factor analysis. Unpublished manuscript. 
OJK. (2020). Survei Nasional Literasi dan Inklusi Keuangan 2019. In O. J. Keuangan (Ed.).

Varcoe, K., Martin, A., Devitto, Z., \& Go, C. (2005). Using a financial education curriculum for teens. Retrieved from http://afcpe.org/assets/pdf/vol1617.pdf

Wagner, J. F. (2015). An analysis of the effects of financial education on financial literacy and financial behaviors. (3689481 Ph.D.), The University of Nebraska. Retrieved from https://search.proquest.com/docview/1677183122?accountid=25704 ProQuest Dissertations \& Theses Global: The Humanities and Social Sciences Collection database.

Widyastuti, U., Sumiati, A., Susanti, S., \& Suherman. (2019). Financial inclusion at the bottom of the pyramid: Accessibility, usage and barriers from fishermen's perspective in urban areas. International Journal of Innovation, Creativity and Change, $9(9), 262-279$.

Williams, B., Onsman, A., \& Brown, T. (2010). Exploratory factor analysis: A five-step guide for novices. Australasian Journal of Paramedicine, 8(3).

Xiao, J. J. (2008). Applying behavior theories to financial behavior Handbook of consumer finance research (pp. 69-81): Springer.

Xiao, J. J., Tang, C., Serido, J., \& Shim, S. (2011). Antecedents and consequences of risky credit behavior among college students: Application and extension of the theory of planned behavior. Journal of Public Policy \& Marketing, 30(2), 239245.

Zulaihati, S., Susanti, S., \& Widyastuti, U. (2020). Teachers' financial literacy: Does it impact on financial behaviour? Management Science Letters, 10(3), 653-658.

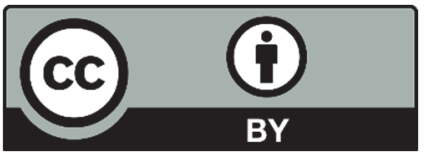

(C) 2020 by the authors; licensee Growing Science, Canada. This is an open access article distributed under the terms and conditions of the Creative Commons Attribution (CC-BY) license (http://creativecommons.org/licenses/by/4.0/). 